\title{
Gene deletion in an Italian haemophilia B subject
}

\author{
F BERNARDI*, L DEL SENNO*, R BARBIERI*, D BUZZONI*, R GAMBARI*, \\ G MARCHETTI*, FCONCONI*, FPANICUCCI $\dagger$, MPOSITANO + , AND \\ S PITRUZZELLO†
}

From * Centro Studi Biochimici sul Morbo di Cooley, Università degli Studi di Ferrara, Via L Borsari 46, 44100 Ferrara; and +Centre for the Study and Treatment of Haemophilia and Haemorrhagic Disorders, University of Pisa, Pisa, Italy.

SUMmARY DNA from 20 Italian haemophilia B patients was analysed by the Southern blotting technique and hybridisation to a factor IX cDNA probe. A large deletion of factor IX gene was detected in one patient with antibodies to the infused factor; the EcoRI pattern of the other 19 subjects examined was normal.

Haemophilia $\mathrm{B}$ is an inherited $\mathrm{X}$ linked disease ${ }^{1}$ caused by a heterogeneous ${ }^{2}$ functional deficiency of factor IX, a glycoprotein involved in the intrinsic pathway of blood coagulation. ${ }^{3}$ The recent cloning of DNA fragments coding for human factor $\mathrm{IX}^{4-8}$ has allowed the identification of a genetic lesion in haemophilia $B^{9}{ }^{10}$ and the detection of an intragenic restriction enzyme polymorphism potentially useful in informative families for antenatal diagnosis. ${ }^{10} 11$

We studied the DNA isolated from 20 Italian males carrying haemophilia B using a cDNA probe for factor IX. ${ }^{8}$ A large gene deletion was detected in one subject, while the DNA patterns of the other haemophilia B patients were indistinguishable from normal.

\section{Subjects and methods}

Blood samples from 20 Italian haemophilia B patients were obtained by standard procedures. DNA preparation and Southern blotting technique were as previously described. ${ }^{12}$ DNA was digested with the appropriate restriction enzymes under the conditions indicated by the supplier (Boehringer, Mannheim).

Thyroglobulin genomic probe was a generous gift from $\operatorname{Dr} E$ Avvedimento.

Hybridisation was performed in accordance with the Gene Screen transfer membrane method (New England Nuclear, Boston). Excess probe was washed off by incubation with $0.06 \mathrm{~mol} / \mathrm{l}$ Tris- $\mathrm{HCl}$ (pH 8), $0.3 \mathrm{~mol} / \mathrm{l} \mathrm{NaCl}, 0.002 \mathrm{~mol} / \mathrm{l}$ EDTA, and $1 \%$ SDS at $60^{\circ} \mathrm{C}$ for one hour, followed by incubation in $0.03 \mathrm{~mol} / \mathrm{l} \mathrm{NaCl}, 0.006 \mathrm{~mol} / \mathrm{l}$ Tris $(\mathrm{pH} 8)$, and 0.0002 $\mathrm{mol} / \mathrm{l}$ EDTA for one hour at room temperature.

Received for publication 24 July 1984.

Accepted for publication 25 September 1984.
Autoradiographs were developed after three to six days of exposure.

\section{Results}

The DNA from the 20 haemophilia $B$ subjects under study were digested with EcoRI restriction enzyme and after Southern blotting hybridised to a factor IX cDNA probe (for which we thank $\mathrm{Dr} G \mathrm{G}$ Brownlee). ${ }^{7}$ Fig 1 shows the autoradiographic frag-

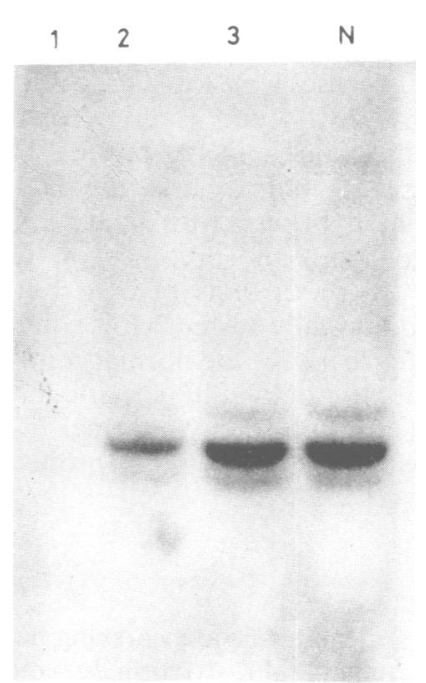

FIG 1 Southern blots obtained from the DNA of three haemophilia B patients and one normal control. DNA was digested with EcoRI restriction enzyme and hybridised to factor IX cDNA probe. I, 2, 3: haemophilia B patients; $N$ : normal control. 


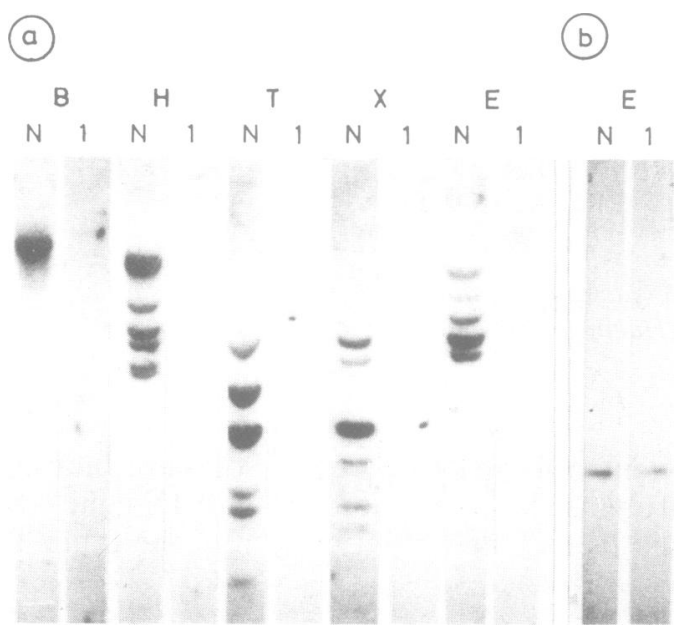

FIG 2 Southern blots obtained from the DNA of case 1 of the previous figure and of a normal control. DNA was digested with BamHI (B), EcoRI (E), HindIII (H), TaqI $(T)$, and $X b a I(X)$ restriction enzymes and hybridised to factor IX cDNA probe (a) and to a thyroglobulin probe (b).

ments obtained in three haemophilia B subjects and one normal subject. The patterns of cases 2 and 3 are indistinguishable from normal.

Similar results were obtained in the other 17 haemophilia B subjects investigated. However, case 1 did not show any hybridisation with the radioactive probe used.

The DNA of case 1 was analysed further using XbaI, TaqI, HindIII, and BamHI restriction enzymes and the same cDNA probe. The results obtained (fig 2a) confirm that the DNA of this patient fails to hybridise with factor IX probe.

In order to assess the presence of hybridisable DNA in the Southern blots of case 1, the EcoRI digest was additionally tested with a thyroglobulin gene probe (fig $2 \mathrm{~b}$ ). Like the normal control, patient 1 showed the thyroglobulin specific $2 \mathrm{~kb}$ band. The DNA of case 1 also gave normal results when hybridised with a $\gamma$ globin gene probe (data not presented).

\section{Discussion}

The DNA of an Italian subject carrying haemophilia $B$, digested with several restriction enzymes, did not show hybridisation fragments when tested with a factor IX cDNA probe. As the cDNA used hybridises to all factor IX exons, the findings obtained indicate that the DNA coding regions were deleted and, since the gene for factor IX is $34 \mathrm{~kb}$ in length, ${ }^{8}$ this is the smallest extent of the deletion, provided that more complex rearrangements are not present.

Large and heterogeneous structural changes in the factor IX gene have already been described by Giannelli et $a l^{9}$ and Peake et al $^{10}$ in the United Kingdom. Neither in the British patients so far described nor in this Italian patient are the end points of the DNA lesion known. DNA sequences 3' and $5^{\prime}$ to the factor IX gene will be needed to determine the precise extent of the lesion, which, as in thalassaemia, ${ }^{13}$ could be very extensive and generated through a similar molecular mechanism. ${ }^{13} 14$

Taken together, previous published reports and the present data indicate that the majority of the gene defects causing haemophilia B are due to small deletions or point mutations, impairing gene expression or the structure-function relationship of the molecule, as in haemophilia B Chapel Hill. ${ }^{5}$

As in the British patients, our patient has antibodies to the factor IX concentrate administered for therapeutic purposes. The other 19 haemophilia B patients considered, whose hybridisation pattern with factor IX cDNA probe was normal, do not produce antibodies to the infused factor IX. These data support the hypothesis of Giannelli et al ${ }^{9}$ that patients with a gross gene defect, leading to the absence of immunologically recognisable factor IX, develop antibodies to the factor, which make its infusion inefficient.

We thank Dr G G Brownlee for the factor IX cDNA probe, Dr E Avvedimento for the thyroglobulin genomic probe, and E Mariotti and V Margutti for preparing the manuscript. This work was supported by the Progetto Finalizzato Ingegneria Genetica e Basi Molecolari delle Malattie Ereditarie of the CNR, contratto No 82.02360.51 and Ministero della Pubblica Istruzione.

\section{References}

1 Ratnoff OD. Hereditary disorders of haemostasis. In: Stanbury JB, Wyngaarden JB, Frederickson DS. The metabolic basis of inherited diseases. New York: McGraw-Hill, 1978:1755-91.

2 Panicucci F, Sagripante A, Conte B, Pinori E, Vispi M, Lecchini L. Characterisation of heterogeneity of haemophilia B for the detection of carriers. Haemostasis 1980;9:310-8.

3 Jackson CM, Nemerson Y. Blood coagulation. Ann Rev Biochem 1980;49:765-811.

4 Jaye M, De La Salle H, Schamber F, et al. Isolation of a human antihaemophilic factor IX cDNA clone using a unique 52-base synthetic oligonucleotide probe deduced from the amino acid sequence of bovine factor IX. Nucleic Acids Res 1983;11:232535 .

5 Choo KH, Gould KG, Rees DJG, Brownlee GG. Molecular cloning of the gene for human anti-haemophilic factor IX. Nature 1982;299:178-80.

6 Kurachi K, Davie EW. Isolation and characterisation of cDNA coding for human factor IX. Proc Natl Acad Sci USA 1982;79:6461-4. 
${ }^{7}$ Camerino G, Grzeschik KH, Jayc M, et al. Regional localisation on the human $\mathrm{X}$ chromosome and polymorphism of the coagulation factor IX gene (hacmophilia B locus). Proc Natl Acad Sci USA 1984;81:598-602.

${ }^{8}$ Anson DS, Choo KH, Rees DJG, et al. The gene structure of human anti-haemophilic factor IX. European Molecular Biology Organization Journal 1984;3:1053-60.

9 Giannelli F, Choo KH, Rees DJG, Boyd Y, Rizza CR. Brownlee GG. Gene deletions in patients with haemophilia B and antifactor IX antibodies. Nature 1983:303:181-2.

10 Peake IR, Furlong BL, Bloom AL. Carrier detection by direct gene analysis in a family with haemophilia B (factor IX deficiency). Lancet 1984;i:242-3.

11 Giannelli F, Anson DS, Choo KH, et al. Characterisation and use of an intragenic polymorphic marker for detection of carriers of haemophilia B (factor IX deficiency). Lancet 1984;i:239-41.

12 del Senno L, Bernardi F, Buzzoni D. Marchetti G, Perrotta CM, Conconi F. Molecular characteristic of a non-deletion $\alpha$ - thalasssaemia of the Po river delta. Eur $J$ Biochem 1981:116:127-30.

13 Vanin EF, Henthorn PS, Kioussis D, Hrosveld F, Smithies O. Unexpected relationship between four large deletions in the human $\beta$-globin gene cluster. Cell 1983:35:701-9.

${ }^{14}$ Lauer J, Shen CKJ, Maniatis T. The chromosomal arrangement of human $\alpha$ like globin genes: sequences homology and $\alpha$-globin gene deletions. Cell 1980;20:119-30.

15 Noyes CM. Griffith MJ, Roberts HR, Lundblad RL. Identification of the molecular defect in factor IX Chapel Hill: substitution of histidine for arginine at position 145. Proc Natl Acad Sci USA 1983;80:4200-2.

Correspondence and requests for reprints to Professor F Bernardi, Centro di Studi Biochimici sul Morbo di Cooley, Via L Borsari 46, 44100 Ferrara, Italy. 